This article was downloaded by: [University of Sydney]

On: 14 March 2015, At: 10:58

Publisher: Routledge

Informa Ltd Registered in England and Wales Registered Number: 1072954

Registered office: Mortimer House, 37-41 Mortimer Street, London W1T

3J H, UK

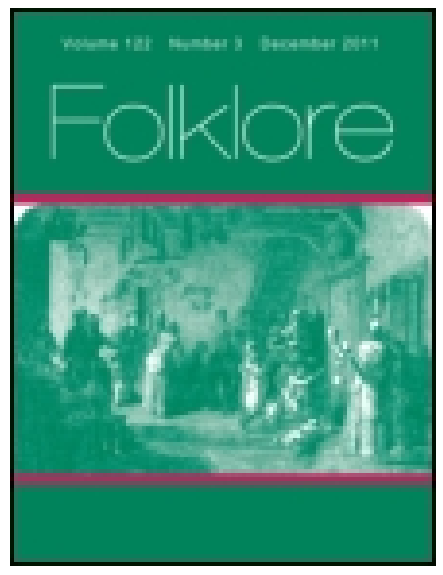

\title{
Folklore
}

Publication details, including instructions for authors and subscription information:

http:// www. tandfonline.com/loi/ rfol20

\section{Australian Marriage Customs}

N. W. Thomas

Published online: 14 Feb 2012.

To cite this article: N. W. Thomas (1907) Australian Marriage Customs, Folklore, 18:3, 306-318, DOI: 10.1080/0015587X.1907.9719780

To link to this article: http:// dx. doi. org/ 10.1080/0015587X.1907.9719780

\section{PLEASE SCROLL DOWN FOR ARTICLE}

Taylor \& Francis makes every effort to ensure the accuracy of all the information (the "Content") contained in the publications on our platform. However, Taylor \& Francis, our agents, and our licensors make no representations or warranties whatsoever as to the accuracy, completeness, or suitability for any purpose of the Content. Any opinions and views expressed in this publication are the opinions and views of the authors, and are not the views of or endorsed by Taylor \& Francis. The accuracy of the Content should not be relied upon and should be independently verified with primary sources of information. Taylor and Francis shall not be liable for any losses, actions, claims, proceedings, demands, costs, expenses, damages, and other liabilities whatsoever or howsoever caused arising directly or indirectly in connection with, in relation to or arising out of the use of the Content.

This article may be used for research, teaching, and private study purposes. Any substantial or systematic reproduction, redistribution, reselling, loan, sub-licensing, systematic supply, or distribution in any form to anyone is 
expressly forbidden. Terms $\&$ Conditions of access and use can be found at http://www.tandfonline.com/page/terms-and-conditions 


\section{AUSTRALIAN MARRIAGE CUSTOMS.}

BY N. W. THOMAS.

To deal seriatim with Dr. Howitt's defence of his position would, I fear, not make for enlightenment, at any rate so far as the casual reader is concerned. I continue the controversy, it is true, more in the hope of eliciting further facts from Dr. Howitt than for any other reason. I have already elicited from him (I) an admission that he has been guilty of a fundamental error in his account of pirrauru in N.T.S.E.A. and (2) the admission that the Kurnai terms maian and bra are not, as he has hitherto implied, strictly analogous to noa.

To reply in full to Dr. Howitt, and in particular to clear up all the errors into which he has fallen regarding my meaning, would be impossible. I can only ask him to read my remarks in the light of my definitions, not of his own. As I shall show below, his own terminology is extraordinarily lax, and to this is due such small confusions as I have fallen into.

It will be convenient to take in order the various points raised by Dr. Howitt's paper and to deal in succession with (I) questions of terminology, and in connection with it (2) Dr. Howitt's theory of social evolution, then (3) the origin of marital terms and the meaning of (4) maian-bra and (5) kandri, and (6) the area in which the pirrauru custom is found. I will then deal briefly with one or two subsidiary points.

Dr. Howitt gives the following summary of limitations 
of marriage on p. 282 of N.T.S.E.A. At the outset there was (i) the undivided commune, where any male could marry any female; this I call " absolute promiscuity." (ii) Then came the segmentation of the tribe into two exogamous moieties, and a man is restricted in his choice of a wife to half the women of the tribe. In practice we find these tribes have regulations which make their marriage customs identical with (iii) the four-class tribes which limit a man's choice to one-fourth of the women of a tribe; (iv) the cross-cousin marriages of these tribes are forbidden by the Dieri, whose rule is identical with that of the eight-class tribes, and limits a man's choice to one-eighth of the women of a tribe.

These three systems I term "limited" or "modified promiscuity," and I term the kinship circle into which a man may marry the "noa-group."

(v) The Dieri and a few other tribes have, side by side with the individual marriage common to all the Australian tribes, a system which provides accessory spouses for married persons or gives unmarried men certain rights over women who are not their individual wives. This is known as pirrauru, and I term the circle which enters into this relation by the name of the "pirrauru-group," or "circle," though it is, in fact, merely a fluctuating set of legal paramours; at most, kandri-made pirrauru seems to be permanent.

In order to make things quite clear I take a typical four-class tribe; not the Dieri, as both their kamirelation and other modifications (legal fictions for facilitating illegal marriages) complicate matters. In such a tribe one-fourth of the women are noa (i.e. potential wives) or marriageable to a given man. In the accompanying diagram the women of such a tribe are shown divided into the four classes: a male of class 4 (in a matrilineal tribe) has the women of class 1 as "father's sisters," of 2 as mother's sisters, of 3 as noa (potential 
wives), of 4 as sisters. If such a tribe were to practise pirrauru a certain number of noa women (who here number 36 ) become accessory spouses to the man; we may take their number at 8 , and show the pirrauru circle by shading the squares indicating the women in question. Finally he has his individual wife, shown here by a black square.

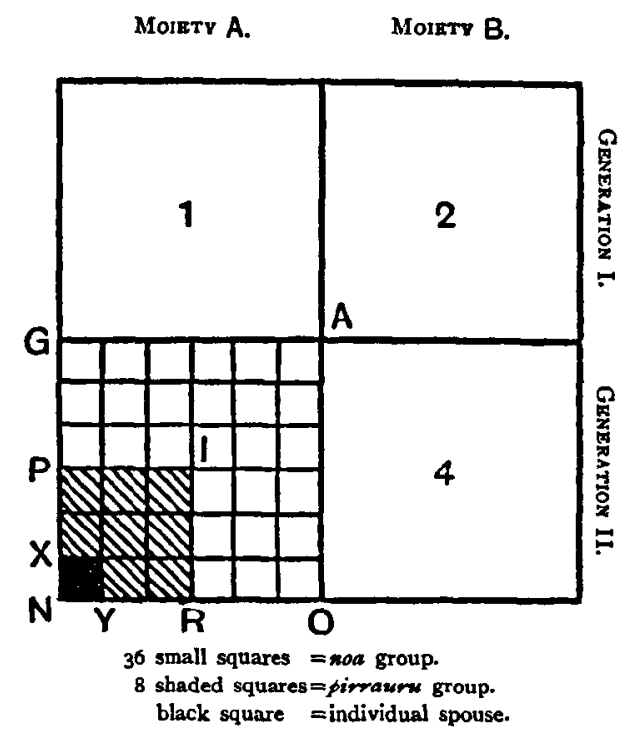

I lay special stress upon the fact that the noa group is wider than the pirrauru group, and that all noa women do not in fact become the pirrauru of any single man, nor all noa men the pirrauru of any individual woman. I now turn to Dr. Howitt's paper.

The first point to which I wish to call attention is Dr. Howitt's failure to formulate a consistent theory. On p. 17I he asserts that what I call "modified promiscuity" must have preceded the creation of the noa group, that is to say that there was no stage intermediate between absolute promiscuity and the pirrauru marriage 
of the present day. On p. 174, and again at the top of p. 177, without perceiving that he is contradicting his previous statement, he asserts that "the application of the term ngaperi to the other brothers who have not become pirrauru" (i.e. to all the men of the noa group) appears to be a vestigiary survival of what was once a fact. That is to say that between the "absolute promiscuity of the undivided commune" and the pirraure marriage of the present day there was a stage, in which all the men of one noa-group were de jure husbands of all the women of another; and this view he emphasises on p. 181 , where he asserts that the kandri ceremony is a restriction of the range of license within the noa group and creates the pirrauru group, while the noa relationship is itself a restriction on a former wider range of licence (i.e. absolute promiscuity). In order to make Dr. Howitt's error quite clear, I now quote from p. 172 (cf. the passage at the bottom of p. I77, contradicting that at the top) a sentence in which he affirms the view stated in the first of these three passages: "I consider the noa relationship as having restricted the range of an earlier and wider license to the present limits of the pirrauru marriage."

On p. 174, on p. 176 and on p. 183 , Dr. Howitt charges me with not understanding the facts of noa and pirrauru. If this were in fact so, I should have ample justification in the confusions just quoted; but in fact the three passages from my remarks on those pages are absolutely accurate, and would have been clear to Dr. Howitt, even if he did not agree with them, had he read them in the light of my definitions and not tried to take my terminology in a sense of his own.

On p. 17r Dr. Howitt remarks, "Throughout my paper I spoke of pirrauru as group-marriage." As a matter of fact Dr. Howitt uses both group-marriage and pirrauru in two different senses, sometimes enlarging the 
pirrauru circle and making it equivalent to the noa group, sometimes narrowing the noa to make it coincide with the pirrauru group (see Fig. I). In Folk-Lore, xvii., p. 104, Dr. Howitt says that the tribes whose kinship terms he has just quoted had pirrauru marriage; among the tribes in question is the Arunta, and the term which Dr. Howitt mentions as in use among them is the word unawa (=noa). Now, as my diagram shows and as Dr. Howitt cannot but admit when he is challenged, the noa group is not as a rule co-extensive with any one pirrauru group, though it includes it; pirrauru is therefore used in this passage in the sense of noa-group-marriage. When, therefore, Dr. Howitt speaks of pirrauru, we are uncertain whether he means the extant Dieri custom or the conjectured institution which he asserts on p. I8I to have been restricted by the kandri ceremony.

Conversely, Dr. Howitt speaks of pirrauru as groupmarriage (xvii. $185, x$ viii. 17 I, 185 , etc.), and at the same time asserts the former existence of another kind of group-marriage among the Kurnai, whose terms maianbra, as I shall show below, correspond not to pirrauru, but to noa, in all essentials, Dr. Howitt's affirmation notwithstanding. There are therefore not only two kinds of pirrauru, but also two kinds of group-marriage, and Dr. Howitt leaves his readers to guess which he means in any particular passage. If he is misunderstood, his blood is on his own head.

(3) I now pass on to the third point of those mentioned above-the origin of the marital terms. Dr. Howitt asserts (p. 170) that "the (group) terms, husband and wife, father and mother, son and brother, all arise out of the pirrauru family." If by this Dr. Howitt means pirrauru in its only proper sense, that in which it is used by the Dieri, this statement is unfortunately absolutely misleading. Dr. Howitt has shown nothing of the sort and can show nothing of the sort, for the 
simple reason that, as my diagram shows, the noa group is not co-extensive with any one pirrauru group, but more extensive, whereas use of the kinship terms mentioned by Dr. Howitt is limited by the noa group and not by the pirrauru group. A boy, for example, in the Dieri tribe applies the term ngaperi to the primary husband of his mother ( $\mathrm{X} Y$ in diagram $^{1}$ ), whether he is actually his progenitor or not, and ngaperi-waka to all his father's tribal brothers (NOAG), whether they are his mother's pirrauru (PIRN) or not. Dr. Howitt in fact admits as much on p. 174, line 21; yet he argues all through as if the pirrauru group were the limit of these kinship terms. Dr. Howitt's argument on p. 179 about the "group-mother" is vitiated by precisely the same error; no one who reads the passage would gather that a boy applies the term which we translate by the word mother, not only to his actual mother and to all the pirrauru spouses of his father, but also to all the women of his father's noa group, even to babies in arms; yet such is the case, though Dr. Howitt's argument is thereby reduced to an absurdity. Put in bald terms it comes to this: that the twenty-seven women of the noa group who are not pirrauru to a given boy's father are addressed by that boy as mothers, because eight or nine other women have relations with his father. Comment is needless.

In connection with marital terms, I must once more refer to my point as to ngaperi and mungan (xvii. 303). I charged Dr. Howitt with being guilty of a grave confusion in asserting that to the ngaperi-waka (Dieri) who is also pirrauru, is analogous in position the breppa-mungan (Kurnai). But little of Dr. Howitt's reply has any bearing on my contention, and what little does bear on it leaves my position absolutely untouched.

${ }^{1}$ For the text here the roa-group must be taken as composed of males, the wife belonging to class 4 . 
As I stated, the ngaperi is the primary husband of the woman, but not necessarily the progenitor of the boy who applies to him the term ngaperi; ngaperi-waka is applied by a boy to all the men who are noa to his mother; some of them are, some are not pirrauru to her, but all are equally ngaperi-zwaka to him; if one of the pirrauru is his father, this man is ngaperi-waka (little father) just as much as a man who never has relations with his mother. It is therefore absolutely clear that these two terms, ngaperi and ngaperi-waka, refer to status in the tribe and in the family and not to paternity, for, as anyone can see, the distinction between "father" and "little father" takes no account of paternity.

The Kurnai terms mungan and breppa-mungan are, so far as we know, used just as the Dieri terms just discussed; and if Dr. Howitt had asserted no more, there would have been nothing to criticise in his remarks. What he actually asserted, however, was that the breppa-mungan (=ngaperi$w a k a)$ of the Kurnai corresponds to the pirrauru spouse of the Dieri. In reply to this it is sufficient to say that all ngaperi-waka are not pirrauru, as they should be if Dr. Howitt's assertion were not entirely misleading.

Dr. Howitt has, in fact, no reply to make to my charge that he is guilty of a grave confusion in his statement of the case. His case depends on the assumption that the breppa-mungan of the Kurnai is the pirraure husband of the Dieri, only in the former case the actual rights are obsolete. But the Kurnai have no institution and no terms corresponding to pirrauru; their terms actually correspond, as I show below, save only that they are post-matrimonial, to noa.

In connection with marital terms, Dr. Howitt makes an important concession (p. 179) in reply to my criticism on one point. He admits that the term used by the Arunta to denote the husband of a boy's mother does 
not mean father, for them. Probably he does not perceive the full importance of his admission; for it is fatal to his argument from marital terms of all sorts.

It is improbable that the Arunta term had an origin entirely different from that of all the others enumerated by $\mathrm{Dr}$. Howitt; we may therefore take it that either the Arunta have forgotten that the term means father, or the other tribes have learnt that it means father while the Arunta have still to gain the knowledge. Now the latter case is clearly fatal to Dr. Howitt's contention; in the former case it remains for him to show that the term translated father was not extended by the other tribes to mean persons other than the progenitor, during a period of nescience similar to that which Dr. Howitt now admits for the Arunta.

Either way, therefore, Arunta nescience is a fatal stumbling block to Dr. Howitt.

(4) I now come to the question of the Kurnai terms maian and bra. Dr. Howitt, for the first time, says that these terms are only post-matrimonial. It is unfortunate that he has not told us so before; at most he has (N.T., p. 169) said that they include husband, wife, brother-in-law, sister-in-law, whereas he translates noa by potential husband or wife. This is at best a very dim revelation. But as Dr. Howitt ( $F$. xvii. 177) omits the "potential" in speaking of the Dieri, even this means of getting at the facts was denied me. I never denied that the maian-bra group included the husband and wife. If Dr. Howitt had told us the real facts I should have modified my sentence (xvii. 297) to read: "They do not imply sexual relations between the parties who apply these terms to each other, save in the case of the individual husband and wife." It is clear that this in no way modifies my point that maian-bra does not correspond to pirrauru, which does imply sexual relations between others besides the individual husband and wife. 
It is interesting to learn that maian-bra are postmatrimonial; but that they are so in no way invalidates my assertion that the maian-bra group corresponds to the noa group, not to the pirrauru circle. For, as Dr. Howitt admits, the pirrauru group does not contain all the tribal brothers or sisters of a given member of it; but the term maian is applied to all tribal brothers and sisters of the husband, the term bra to all sisters of the wife. Will Dr. Howitt tell us wherein they differ from the kinship terms which are limited by the noa group?

I may add that Dr. Howitt's point that maian-bra is post-matrimonial tells against himself with equal force. Or does he seriously assert that pirrauru is subsequent to individual marriage and a necessary corollary of it? If not, what is the point of saying that my contention as to maian-bra is wrong, because maian-bra are, like brother-in-law and sister-in-law among us, terms resulting from and acquired at individual marriage? Not only so, but how can Dr. Howitt assert that maian-bra mean husband and wife and that they point to a period of group marriage, when the wife applies the same term maian to her husband and to his sister? Does Dr. Howitt maintain that the wife was originally the wife of her husband's sister? If not, it is clearly not conclusive of the prior existence of group marriage that other men besides the husband are called maian.

(5) On p. 179 Dr. Howitt asserts that the kandri ceremony announces the betrothal of a male and female noa. On p. 176 he assures us that people who are made tippa-malku cannot be again betrothed; yet in dealing with the kandri ceremony (p. 179) he asserts the very reverse. It is probably merely another case of loose terminology. However this may be, the betrothal ceremony to which he invites my attention has absolutely no relation to the kandri as described in N.T.S.E.A., p. 181. There it is represented that the individual 
marriage has nothing to do with the kandri ceremony, and Dr. Howitt repeats in his reply to me (p. 167) that the kandri ceremony has to do with pirrauru. But if the betrothal ceremony of the Kuinmurbura, prior to individual marriage, is a parallel to the kandri ceremony, all this is erroneous. I fear Dr. Howitt has not mastered his facts.

(6) Dr. Howitt asserts (p. 184) that I omit to mention the dilpa-malli relation. I did not omit it (see p. 3OI, lines I1-12), though so far there is no evidence that it corresponds exactly to pirrauru. All that is asserted by Dr. Howitt (N.T., p. I93) is that a group of men and women cohabit at certain times. But this is not pirrauru, which involves a ceremony to initiate it. Moreover, Dr. Howitt seems very uncertain as to the reliability of the information: he says, "according to my informant"-a formula which he does not use in speaking of the Dieri, though his information about them too has now turned out to be erroneous on a point of fundamental importance. Not only so, but Dr. Howitt (N.T.S.E.A., p. 97) includes the Kurnandaburi among the Lake Eyre tribes, i.e. the Dieri nation. I may add that before Dr. Howitt argues that dilpa-malli is the equivalent of pirrauru, he should at least tell us what individuals constitute the group, whether all tribal brothers and sisters (i.e. the noa group) or only some of them; and in the latter case how they are selected. As to the Yantruwunta, I understand Dr. Howitt to class them too with other tribes of the Dieri nation (N.T.S.E.A., pp. 90-92).

I have, so far, barely alluded to the amazing admission with which Dr. Howitt opens his reply to me. Not once, but several times, it is asserted in his Native Tribes that tippa-malku precedes pirrauru. This now goes by the board, though Dr. Howitt does not allow us to judge of the quality of the evidence on which he relies. As the Dieri are stated to have been decadent for more 
than thirty years and to be gathered upon the mission stations, I submit that we have no trustworthy evidence.

In this connection I need hardly point out that the two views cited by Dr. Howitt on p. 166 are in reality not inconsistent at all, unless we know that at the kandri ceremony to which the statement refers there were marriageable girls; and this we do not know. Women being scarce-there do not seem to be more than ten of all ages in the tribe to whom a man is noa-it is probable that they are all betrothed and married as soon as they are initiated; at any rate it lies with Dr. Howitt to show that his view is right.

In any case it seems clear that the kandri ceremony is but rarely performed, for otherwise it would not be necessary for a widower to give presents to his brother in order that the wife of the latter may become his pirrauru; in fact, this custom seems to throw doubt on the permanence of pirrauru altogether; for why should a man who has a pirrauru, as an elderly man presumably has, set out in quest of fresh adventures?

Space fails me to discuss all the points at which Dr. Howitt accuses me of ignorance of the Australian facts or of other misunderstandings. If space permitted it would be easy to show that these charges are all groundless; but I can only take a few cases. On p. I7I Dr. Howitt takes one of my sentences, and construes the term "group-marriage" in his own sense, not in mine, and proceeds to reply on that supposition. Controversy is really impossible if one is not allowed to define one's own terminology; as I have shown, Dr. Howitt's is too defective to permit me to put his terms alongside of my own as a means of avoiding misunderstanding. But I really must claim the right to use my own terms.

Again, on p. 174, Dr. Howitt says I have not mastered the facts of the noa relation; his only ground for doing so is because I say that the classificatory system is a 
legal system. He himself admits that noa means "marriageable"; it is expressive of status, not of actual marital relations (though it includes these); and that is what I mean by the term "legal"; what Dr. Howitt thinks I meant is a mystery to me.

Again, on p. 176, Dr. Howitt says I have not mastered the evidence as to pirrauru and tippa-malku, because I say that both are entered upon by individuals, etc. All I mean by this is that a man (so far as I can see) gets, or may get, his pirrauru spouses one by one, not as a group; I do not assert that he has not more than one pirrauru, as Dr. Howitt could easily have seen by several passages (see p. 299, where I speak of pirrauru as a combination of polyandry and polygyny, an impossible remark if I did not recognise that there are several pirraurus to each individual).

To sum up: (I) Dr. Howitt admits having made an error of fundamental importance in the matter of pirrauru; even now we have no clear statement as to how many ways exist of becoming pirrauru or of entering into individual marriage; so far as I can make out there are four of each.

(2) Dr. Howitt denies the validity of my assertion that he wrongly put maian-bra on a level with pirrauma; I show that I am entirely justified in my contention.

(3) Dr. Howitt throws over all that he has said in his book about kandri, and brings it into relation with individual marriage, unless his whole point in his present remarks is, as I suspect, entirely erroneous.

(4) He speaks of pirrauru as group-marriage, and argues as if the group in question were made up of all the noa; he alternately asserts and denies that noa-group-marriage existed, and where he asserts it he speaks of it as pirrauru. His terminology seems to be hopelessly inadequate.

(5) He will not permit me to select my terms and 
define them as I choose; but insists on construing them in the sense in which he himself uses them; and is then surprised that he cannot understand me or that I seem to contradict myself.

(6) He has not produced an individual term for mother, though he admits that individual mothers were known. Yet he still argues that individual marriage must have caused an individual term to arise. This is, "Heads I win, tails you lose."

I may remark in conclusion that I did not claim for myself any special power of interpretation, for my criticism of Dr. Howitt was purely negative. But I do claim that I say what I mean and mean what I say, that my terminology is adequate, and that my conclusions are drawn from my premisses.

I trust that Dr. Howitt will soon publish his corrections to N.T.S.E.A. At present we really do not know what to accept. It is strange that Dr. Howitt did not discern his mistake as to pirrauru earlier, for, had he done so, he would surely have taken the first opportunity of putting things right.

Northcote W. Thomas. 